\title{
Editorial
}

\section{Psychological Factors Motivating the Intention to Utilize Mass Transport Vehicles}

\author{
Juneman Abraham \\ Department of Psychology \\ Bina Nusantara University
}

\begin{abstract}
The field of transportation psychology has yet to develop rapidly in Indonesia. Inner city transportation council members with an educational background in psychology are still quite rare. There is only one professor in transportation psychology. On the other hand, transportation problem increases in both quantity and quality, especially in major cities. One main source of transportation problem in cities is the lack of willingness of people to use mass public transport vehicle, resulting in traffic jams in main roads to other alternative roads. The current theoretical review article aims to show the various psychological variables that are capable of predicting motives and intentions of individuals to use mass public transport vehicle. Such psychological knowledge is expected to contribute as a possible suggestion of an intervention supporting the effort of the government in the development of transportation facilities and infrastructure, transport regulations, and economic policies related to transportation.
\end{abstract}

Keywords: transportation psychology, mass public transport vehicle, intention, city dweller behavior

Bidang studi psikologi transportasi di Indonesia belum berkembang dengan pesat. Anggota Dewan Transportasi Kota yang berlatarbelakangkan pendidikan psikologi masih sangat langka. Profesor dalam psikologi transportasi di Indonesia pun saat ini hanya ada seorang. Sementara itu, permasalahan transportasi, khususnya di kota-kota besar, semakin meningkat kuantitas dan kualitasnya. Salah satu pangkal permasalahan transportasi di kota adalah enggannya orang menggunakan angkutan umum masal, yang menghasilkan kemacetan di jalan-jalan raya sampai di jalan-jalan alternatif. Kajian teoretis dalam artikel ini memperlihatkan variabel-variabel psikologis yang mampu memprediksikan niat atau intensi orang menggunakan kendaraan umum masal. Pengetahuan dari sisi psikologis ini diharapkan dapat menjadi masukan serius bagi intervensi yang bersifat mendukung upaya yang sudah dan sedang dilakukan oleh Pemerintah dari sisi pembangunan sarana dan prasarana fisik transportasi, pengaturan penggunaan jalan, dan kebijakan ekonomis yang terkait dengan transportasi.

Kata kunci: psikologi transportasi, angkutan umum masal, intensi, perilaku warga kota

Traffic jam is a classical problem in big cities that decreases the quality of life, environment, and competitiveness of a city (Transport Advisory Committee, 2014). This problem cannot be solved purely by infrastructure development such as making more roads, because new roads will create new traffic "demands"

Correspondence concerning this article should be addressed to Juneman Abraham, Department of Psychology, Faculty of Humanities, Bina Nusantara University, Jl. Kemanggisan Ilir III No. 45, Palmerah, DKI Jakarta 11480. Email: juneman@binus.ac.id that in turn will increase traffic; even now, the use of roads has created a tragedy of the commons because everyone wants to "reap the benefits" by maximizing their road usage (Juneman, 2010). As such, there is increasing demand to manage the urgent need for mobility in cities, for example by encouraging the behavior of using mass public transport to warrant the sustainability of activities in big cities (European Commission, 2004). In this context, transportation psychology plays a role in understanding psycholo- 
gical variables affecting the choice of transportation modes, for example by using the behaviorist approach or social psychological approach (Novaco, 2001). Transportation psychology is defined as:

"...the study of human behavior and well-being in conjunction with the regularized movement of people, goods, and services regarding work, personal life, and community activity systems. In addition, it involves the interface of humans with transport vehicles and facilities, including their design for optimal operation, provisions for human needs, forms of utilization, and social impacts." (Novaco, 2001, p. 15878)

According to Sjafruddin (as cited in ITB News, 2013), development of new roads can only be seen as a temporary solution to traffic jams. Incentive/ disincentive programs for many types of vehicles are not optimally functioning due to the fact that the implementations of such programs are not free from corruption (Rizky, 2014). In other words, the behavior of individual city dwellers is the key to saving the city from traffic disasters. In this case, it is hoped that a growing number of city dwellers will realize the importance of using public transport to fulfill their daily needs.

Existing research regarding factors that predict and/or affect public transport ridership can be categorized into two factors: objective and subjective factors. In a qualitative study done by Beirão and Cabral (2007), objective factors include cost, travel time, pollution, time uncertainty, difficulty of parking, crowd, safety, and isolation. Examples of subjective factors are a lack of control, lack of flexibility, freedom, and stress of driving. The author noted that the classification of subjective (related to personality, perception, attitude, and individual lifestyle) and objective (things that occur or are actually done) at the beginning of this article aims to increase readability and comprehension. Such classification is also done by Cao and Mokhtarian (2005) as well as Kamargianni, Dubey, Polydoropoulou, and Bhat (2015).

With regards to subjective factors, there are some theoretical explanations about psychological variables that predict or affect the willingness of individuals to use public transport in various conditions. Such theoretical explanation will be described in the following sections.

\section{Theory of Planned Behavior}

One suggestion provided by Chowdhury and Ceder (2013) used the theory of planned behavior (TPB). The TPB approach explained that an individual tends to plan their behavior, and this is done consciously or unconsciously. According to this theory, human behavior is guided by three factors, which are beliefs about the consequences of things related to the behavior (resulting in a specific attitude towards the behavior), beliefs about the expectation of significant others (resulting in the perception of social pressure), and beliefs about things that facilitate or inhibit behavior (resulting in the perception of difficulty of displaying the behavior); these three factors (attitude towards behavior, subjective norm, and perceived control) forms the base for behavioral intentions that will be done when there are no actual obstacles to do the behavior (Ajzen, 2002).

Chowdhury and Ceder (2013) discovered the presence of a psychological model on individuals who have the intention to use public transport. This condition is often found on people who need to transfer from one station/terminal to another before reaching their destination. By applying TPB, they found that self-efficacy (a component of perceived behavioral control/PBC) is a predictor of intention to use public transport vehicle. The level of self-efficacy can be predicted by the level of confidence and perceived

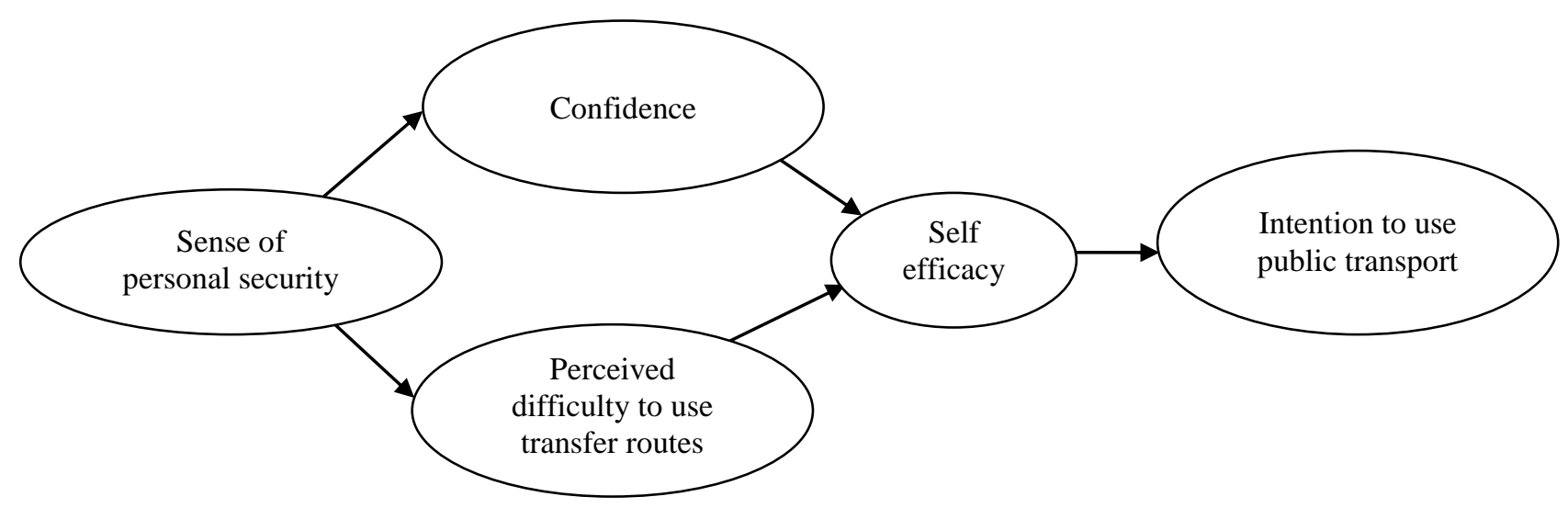

Figure 1. Diagram depicting the model of factors affecting intention to use public transport. 
difficulty to use transfer routes. The two aspects are closely related to personal security. Visually, the relationship among the constructs is presented in Figure 1.

Heath and Gifford (2002) in particular did a study on students regarding the psychology of universal bus pass programs, related to the transition of using transport modes from personal to public vehicles with a TPB framework. Similar to Chowdhury and Ceder (2013) who found the importance of PBC and intention, Heath and Gifford (2002) found that the interaction between PBC and intention can predict such transition. The difference is that Heath and Gifford suggested that PBC was not a predictor of intention, but rather has a direct interaction with the intention (a modification of the original TPB) when explaining the largest variance of bus ridership behavior. In addition, another difference is that they also found how descriptive norm (number of friends who use public transport in specific situations) have a more important role than the subjective norm (matched with injunctive norm; opinion of significant others regarding the morality of using public transportation). This is in contrast to the finding by Popuri, Proussaloglou, Ayvalik, Koppelman, \& Lee (2011) that the choice of transportation mode is significantly influenced by one's immediate family and friends (leaning more towards injunctive norm). Popuri et al. stated the implication of this finding, that is, there needed to be incentives to subsidize public transport riders to include their friends to ride public transports. However, such suggestion should be investigated further for its concrete implementations.

Higurashi and Macer (2001) found in their empirical study that the awareness of Japanese people regarding their environmental crisis did not reduce their use of private cars. Interestingly, in line with research using TPB framework earlier, the analysis of Higurashi and Macer (2001) stated that "people just lack the ability to apply them to practice to challenge their lifestyle and the peer pressure that demands consumption" (p. 41). This statement closely reflects the concept of PBC and subjective norm in TPB.

Based on previous studies, $\mathrm{PBC}$ and social norms (subjective and descriptive norms) are consistent pivotal predictors of intention to use public transport vehicles.

\section{Psychology of Waiting}

Currie (2012) gave a summary regarding the psychology of public transport passengers, in this case, their thoughts and emotions. Explanation about this psychology is important because it gives a description of salient things that are part of the initial consideration to use public transport vehicles.

Currie stated that propositions from Maister (2005) about "psychology of waiting" can be applied to psychology of public bus passengers. For example, (1) anxiety makes waiting feel longer (for example, anxiety of an individual in a bus stop can arise from looking at cars passing by to reach their destination while the individual waits); (2) waiting for an indeterminate amount of time (or for unclear reasons) feels longer than waiting for a specific amount of time (or for a clear reason) (for example, waiting for a bus with an unpredictable schedule feels longer); (3) waiting in a situation perceived as unfair feels longer than waiting in a situation perceived as fair (for example, waiting for a busway bus that can be predicted as being full of passengers from the departure terminal; waiting in a queue with a queue jumper); (4) Passengers are more willing to wait for longer if the service is deemed valuable (for example, the bus is safe and comfortable); (5) waiting in a long queue results in heightened alertness; waiting in shorter queue results in a relaxed state. With this knowledge, intention to use public transport can be increased by applying interventions on the stated variables.

\section{Cognitive and Affective Aspects}

Another comprehensive study regarding the psychology of public transport users is done by Dziekan (2008). By using a cognitive psychology approach, he found two important things in a context of public transport in a metropolitan city. The first is the finding regarding a hierarchy of knowledge about public transport, starting from (the lowest) being aware of the existence of public transport than can be chosen, knowing the mode of public transport (bus, train, busway), to (the highest) knowing the details of color, number, and routes. In relations to the cognitive perspective of the user, there are three things making up the memory representation of a user of public transport, which are route label, visibility in the urban route, and straight route layout. The second finding, perception about the ease of use of public transport was contributed by trunk bus lines, and real-time displays shown by trunk bus stops increases memory representations about public transportation system (spatial-temporal aspects). This knowledge hierarchy should be understood to devise a strategy for making public transportation more salient in the minds po- 
tential users of public transport, for ease of access and ultimately for resulting in the act of actually using it.

Dahalan, D'Silva, Abdullah, Ahmad, \& Ismail (2014) also found moderate prejudice towards public transport users in Klang Valley, Malaysia young people. It was illustrated in an item in the questionnaire: "The only reason to use public transport is if you can't afford to drive." Such negative attitude needs to be addressed because it will undermine any effort done to improve public transport services. Beirão and Cabral (2007) also addressed this problem; however they called the problem as misperceptions and negative images. They further argued that the prejudice originates from those who never use public transport, or have used it once a long time ago, so they lack current knowledge about the development of public transport. Such individuals also tend to base their argument on brief observations of the length of queue at bus stops and other temporary complaints given by others around them regarding the conditions of public transport vehicles. Another prejudice is the idea that public transport users are those who have "no mobility freedom, no money, old, poor, unemployed" (Mitrea \& Kyamakya, 2013 , p. 495). Thus, a suggested recommendation is to change public perception and to market attractiveness and positive symbolism of public transport.

Stradling, Carreno, Rye, and Noble (2007) identified the likes and dislikes of public transport (bus) users in their urban journey. In Edinburgh, Scotland, Stradling et al. found through qualitative research eight factors that form an individual's likes or dislikes towards public transportation, and all eight of them are a combination of objective and subjective factors. The first one is security (including the unsafe behavior of copassengers, or behavior that disrupts comfort; the feeling of lack of safety of using bus at night, the absence of security or bus conductor; the feeling of lack of safety when waiting for the bus, especially at night). Second, is unwanted arousal (including speeding driver, passenger density and lack of ventilation, passenger sneezing without covering his/her nose/ mouth, smoking passengers, poor seating space due to lack of leg room, loud speaking noises). The six other factors are: preference for car use (e.g. "I feel more in control when I drive"); self-image (e.g. "My clothes/ footwear are often not appropriate for bus travel", "Travelling by bus does not create the right impression", "Do not like the image of buses"); problems with service provision (e.g. "No direct route", "Not sure if I will get to my destination at the right time", "The bus service is too infrequent"); cost (e.g. "The fares are not good value for money"); preference for walking or cycling (e.g. "Most things are within walking distance", "I prefer to cycle"); and disability and discomfort (e.g. "Having to ask people to move to let me out when it is my stop", "There are not enough hand rails inside the bus").

The similarities between the findings by Beirão and Cabral (2007) and Stradling et al. (2007) are the fact that both highlight positive experiences as a motivating factor to use public transport. In terms of differences, Beirão and Cabral stated that efforts to increase positive experiences need to be complemented with intervention on the image that a person has towards public transportation. This image is like a lens that will filter and process each and every actual improvement on various aspects of public transport. If the lens is "blurry" then the actual field improvements will be "more difficult to see" and thus it will be harder to convert personal vehicle users into public transport users. This is due to the fact that some people may remember more positive experiences of using personal vehicles compared to using public transport. Stradling et al. have actually included self-image factor that included an image of public transportation. However, the image factor explained by Stradling et al. is more descriptive and lacks adequate logical explanation to support the idea, compared to Beirão and Cabral.

Other research lends evidence on the existence of heuristics and cognitive biases in choosing transportation modes. Innocenti, Lattarulo, and Pazienza (2013) found that although participants are often faced with the fact that using a metro is, in general, more efficient in terms of time and cost compared to using a private vehicle, and although they have been faced with multiple opportunities to change their decision, the variable of "car stickiness" made them prefer riding their own private vehicle. This is caused by "the first choice effect": "Once a travel mode is chosen, rational calculation plays a limited role in determining decisions, and subjects' decisions are driven by heuristic reasoning" (Innocenti, Lattarulo, \& Pazienza, 2013, p. 167). This statement contains two main variables, which is habituation in decision making (such that decisions are made not deliberately or involving some consideration) and emotional attachment to the car. Related to habituation, this was also found earlier by Aarts, Verplanken, and van Knippenberg (1997), that "habit reduced the elaborateness of information use in judgments of travel mode use" (p. 1).

In relations to emotional attachment to the car, Innocenti et al. (2013) explained that the symbolisms of freedom and status brought about by having a car 
contributed to car owners being less affected by the monetary cost that needs to be paid by car drivers and the monetary incentive provided by using public transport vehicles. Sohn and Yun (2009) summarized this as a "sense of personal identity" obtained by car owners. This implies that high amount of tax for personal car users and subsidization for public transport have little role in the decision to use public transport because cars themselves offer symbolism (containing important values) and identity for an individual.

The issues of favorability and stickiness to a car have already been predicted by Bronner (1982) in their research in the Netherlands, where it was found that for car travelers, the values of independence and privacy, as well as freedom from waiting for the bus/ metro/tram play very important roles. He compared this with train travelers who stressed the opportunity to read or work on the train (value of productivity), as well as freedom from tension, traffic, and effort to find a parking spot. Findings of this study can be applied in the urban context such as in Jakarta that has become increasingly individualistic. This possibility-based on values of identity, independence, and privacy - is supported by the research done by Sheller and Urry (2004) who stated that automobility is a central factor in a consumeristic culture that in reality is individualistic and affective (recall that identity is strongly related with affectivity in characterizing individual distinctiveness; Lucente, 2008; Zabrowski, 2013); in which case automobility is seen by drivers as paradoxically offering a solution to traffic problems thathe/she realizes - is indeed a consequence of his/her own decision to drive a car (in line with the "sense of independence"), and that cars have the ability to protect the passenger (giving a "sense of privacy").

More specifically in the context of the Greater Area of Jakarta (Jabodetabek), Indonesia, the finding by Innocenti et al. (2013) is supported by Sumaedi et al. (2014) who stated that the predictor of behavioral intention of public transport ridership is image, with a direct and indirect effect (through the variable of perceived value). The image in this context is a "mental picture of the offering that includes symbolic meanings consumers associate with a specific land transport service" (Sumaedi et al., 2014, p. 24), and includes the hedonic experiential dimension or emotional non-functional aspect of transportation mode. Sumaedi et al. explained that objective service quality is undermined by the subjective image.

However, Sumaedi et al. reminded that concluding that service quality (utilitarian/instrumental perspective) of public transport plays no role at all (such that it can be ignored) in driving the use of public transportation is a hasty conclusion. This is because the image that is affective-emotional-subjective tends to support function/utility that has an objective, cognitively perceived quality. This is in line with the statement by Steg (2005, p. 160), "Symbolic and affective aspects significantly contribute to the positive utility of driving."

In other words, image construction of public transport will be meaningless without fulfilling minimum function (ability to deliver passengers safely to their destination; as necessary but not sufficient conditions). However, additional functions over and above minimum functions will also be meaningless without a positive image from potential passengers. Therefore, a balance between affective image and positive experience designed based on function on the hardware side of public transport is very important. Both need to be systematic and simultaneously developed; one cannot be prioritized over another in one period. The findings by Sumaedi et al. insisted that the irrational factors in the choice of transportation mode (private vs. public) needed additional attention.

Using self-completion theory, that stated how an individual tries to find "something" to make meaning of his/her own self-concept and identity, Sumaedi et al. suggested that the image of public transportation should be constructed in such a way that it becomes compatible with the lifestyle and identity of the targeted potential passengers. Therefore, there can be an emotional bond formed between the passengers and public transport vehicles. That is, the link between passenger and vehicle should have a relational aspect. A comparison for this would be the relationship between consumer and brand in the commercial world, analogous with the interpersonal relationship between two individuals (Aggarwal, 2004). One way is through increasing the existence of discourses in the society and schools that owning a personal car is not a reflection of a status symbol. This needed to be instilled early in the process of education.

In addition, an image needs to be created portraying how citizens also "own" public transportation (from the provision model of public transportation), to encourage a feeling similar to owning a car. For example, the correct fare should only be given when the driver, conductor, and transportation institution acts accordingly when driving a public vehicle. Citizens can also "own" public transportation by providing constructive criticisms and suggestions that should be listened to by driver, conductor, and transportation institution. In essence, according to Steg (2005), public policy needs 
to accommodate "compensations" from the loss of symbolism and affectivity, such as feelings of power and superiority that were previously owned by users of private vehicles. This implies that when people realize that public transport "belongs" to them, the desire to use and demand for availability should increase positively. Citizens may also even try their hardest to have a place in public transportation, which in turn requires demand management (Glover, 2013).

From the explanations earlier, it can be seen that cost and benefit factors considered by travelers in choosing the mode of transport are not merely objective factors, and instead subjective factors are more salient. This is in line with Bronner's (1982) view, "It is better to base predictions on perceptions of cost than on the actual costs involved" (p. 90). In the development of studies regarding the motivation to use transport modes, theories are reductionistic if they highlight only one factor and ignore the other. A developed model called Hybrid Choice Model (Kamargianni et al., 2015) connects the effect of both subjective and objective factors. However, the author as a social psychologist stresses subjective-psychological factors as a focus in this article.

\section{Personality Factors}

When discussing subjective factors of the use of public transport, personality variables need to be taken into account because subjective factors are often based on personality. Personality is defined as:

"the dynamic organization within the individual of those psychophysical systems that determine his characteristic behavior and thought... All the systems that comprise personality are to be regarded as determining tendencies." (Allport, 1961, p. 28-29)

There are three aspects of such organization: cognitive, affective, and conative (Bridges, 1925). Personality with these three aspects are assumed to contribute in a person's attitude towards public vehicles, and influences someone to have an intention to ride public vehicle starting to before waiting for the vehicle, waiting for it, getting on the vehicle with all personal and social situations experienced, up until the willingness to transfer to multiple other public vehicles, as described in some of the examples provided earlier in this study. Therefore, we can see the results of studies connecting personality and behavior of using public transportation.

In general, there are two types of personalities, which are personality trait dan personality state (Chaplin, John, \& Goldberg, 1998). Personality traits are stable, resistant to change, and are influenced by a person's inner thoughts, whereas personality state is temporary, transient, and are influenced by factors outside of an individual. In this section, the following personality traits will be discussed: anxiety, excitement seeking, happiness, consideration of future consequences (CFC), environmental personality trait, and OCEAN personality traits.

A number of research have attempted to link personality with choice of transportation mode (private vs. public). Moen (2007) argued that perceived risks in transport ridership are influenced by personality. It was found that among personality aspects, anxiety has an indirect positive effect - through worry-on the priority of safety; whereas excitement seeking has a direct negative influence on safety priority. This means that when designing safe transportation modes, the elements of anxiety and worry need to be considered, for example when designing physical facilities that can reduce anxiety and worry.

Duarte (as cited in Morris \& Guerra, 2015) stated that personality affects the choice of transportation mode. Happiness as a part of personality traits has a role in the context of the European public. Individuals who are happiest chose to bike to and walk to work. Those who are happier tend to choose the metro train than cars. Collins and Chambers (2005) found that in Australian university students, consideration of future consequences (CFC) plays a role as a predictor for preference for public transport. Schwanen and Mokhtarian (2005) found that adventure-seeking personality has a positive correlation with use of private vehicle because such vehicle is more flexible in accommodating spontaneous and non-regular activities, although Sohn and Yun (2009) found negative correlation, which is when adventure seekers were faced with traffic jams. Johansson, Heldt, and Johansson (2006) in their study in Sweden found that environmental personality traits, which are the predisposition to display pro-environmental behavior, such as recycling, can predict the choice of environment-friendly vehicles.

Kim, Schmöcker, Bergstad, Fujii, \& Gärling (2014) found varying predictions from OCEAN (Openness to experience, Conscientiousness, Extraversion, Agreeableness, and Neuroticism) personality traits on acceptability towards the personal vehicle carbon tax policy on Kyoto University students in Japan. This finding is important because transport pricing was found as a variable that affects the use of public or private vehicles (Steg \& Schuitema, 2007).

Kim et al. (2014) further found that only three personality traits predict acceptability. Some of the 
more important findings include: (1) Extraversion is a significant (positive) predictor of acceptability towards environmental taxation, and indirectly through the variables trust in government and perceived fairness. This is because those high in extraversion are more cooperative and possess social attention; (2) Agreeableness has a significant positive prediction on acceptability, indirectly through the variables personal norm and perceived effectiveness. This is because agreeableness is related to empathy, selflessness, and altruism; (3) Conscientiousness positively predicts acceptability, indirectly through environmental problem awareness. This is because conscientiousness is related to aspects such as the determination to achieve long-term goals (environmental problem is a long term goal) and competence. The findings of Kim et al. also support the explanation by Innocenti et al. (2013) who stated that disincentives on private vehicle owners will not be effective if subjective factors - in this case, personality_plays it role, because certain personality traits will make it easier for some people to tolerate such disincentives.

\section{Sedentariness}

Sedentary behavior (sedentariness, or physical inactivity), or behaviors "that involve sitting and low levels of energy expenditure" (Owen, Healy, Matthews, \& Dunstan, 2010, p. 106) also have a chance to affect the low levels of intention to use mass public transport. Previous research showed that sedentariness is contributed by the following behaviors (Biddle, Gorely, Marshall, Murdey, \& Cameron, 2003; Chau et al., 2012): (1) "techno-activities", such as playing video games, using mobile phones, using personal computer/ notebook; (2) non-socializing activities, such as watching television, listening to radio, reading, sitting quietly in a car, occupational sitting; (3) Uninvolved inactivities, such as sleeping. Sedentary behavior does not only mean a complete lack of physical activity, but it also includes low-energy expenditure behaviors such as lying around, sitting in a vehicle, sitting without doing anything, and standing still (Owen, Healy, Matthews, \& Dunstan, 2010; Peavler, 2012).

Saunders (2013) compared the profiles of individuals with low sedentariness (called Ideal/Healthy Movement Profile; IMP) and high sedentariness (called Deleterious Movement Profile; DMP) based on six aspects, as follows: (1) Movement variability (higher on IMP, lower on DMP); (2) Moderate and vigorous physical activity (higher on IMP, lower on DMP); (3) Breaks in sedentary time (higher on IMP, lower on DMP); (4) Total sedentary time (lower on IMP, higher on DMP); (5) Prolonged bouts of sedentary time (lower on IMP, higher on DMP), and (6) Screen time (lower on IMP, higher on DMP). Sedentary behavior is significantly affected by the design of the physical environment that encourages activities dominated with the sitting position, imagery in mass media depicting such comfort, and social environment or community that gives low walkability activity examples (Owen et al., 2011).

The six conditions can be facilitated by private cars, in which private car users can be categorized as a person with DMP profile. This is supported by the reality that roads passed by private cars in urban areas, such as in the Greater Area of Jakarta (Jabodetabek) has become increasingly dense/busy, making passengers sit longer, being still for longer, and have longer screen time (by playing with their phone or tablet). Due to the evidence that sedentariness is "contagious" as a collection of lifestyle, from parents to children (VázquezNava,Treviño-Garcia-Manzo, Vázquez-Rodríguez, \& Vázquez-Rodríguez, 2013), among peers (Sawka, McCormack, Nettel-Aguirre, Hawe, \& Doyle-Baker, 2013), or from one behavior to another (De Baere, Lefevre, De Martelaer, Philippaerts, \& Seghers, 2015), there is a possibility that intervention regarding the use of private cars can be done to reduce sedentary lifestyle syndrome. By accustoming individuals to increased physical activity and reduced sedentary behavior, it is hoped that such activities can be "transferred" into an increase using public transport. People will find it easier to to walk or to begin their journey with mass public transport, to transit between stops or terminals, up until they achieve their destination.

\section{Closing Statement}

This article has explained a number of behavioralpsychological variables explaining the level of intention of an individual to use mass public transport. Such variables include (1) Theory of Planned Behavior, (2) Psychology of Waiting, (3) Cognitive and Affective Aspects, (4) Personality Factors, and (4) Sedentariness, and all have a direct and indirect effect on intention to use mass public transport. Further empirical research is needed, especially for variables (2), (4), and (5), because researchers have yet to corroborate or elaborate those three with regards to their relationship with intention. It is also important to do an empirical study highlighting the psychology of passengers when they are actually on the vehicle, such as the analysis by 
Duvarci, Hult, Johansen, and Munch (2011) using the theory of group boundaries, theory of roles, and theory about public and private space.

The Indonesian government should initiate and support research on transportation psychology. In terms of the use of mass public transport in cities, psychological research needs to be done holistically, starting from a phase where someone considers whether to get out of the house, doing daily activities outside the house, up until the person returns home. Such research model involves direct prediction, mediation, and moderation concerning the intention to use public transport, which has become increasingly urgent to be carried out.

\section{References}

Aarts, H., Verplanken, B., \& van Knippenberg, A. (1997). Habit and information use in travel mode choices. Acta Psychologica, 96, 1-14. Retrieved from http://dx.doi.org/10.1016/S0001-6918(97)00 008-5

Aggarwal, P. (2004). The effects of brand relationship norms on consumer attitudes and behavior. Journal of Consumer Research, 31(1), 87-101. Retrieved from http://dx.doi.org/10.1086/383426

Ajzen, I. (2002). Perceived behavioral control, selfefficacy, locus of control, and the theory of planned behavior. Journal of Applied Social Psychology, 32(4), 665-683. Retrieved from http://dx.doi.org/ 10.1111/j.1559-1816.2002.tb00236.x

Allport, G. W. (1961). Pattern and growth in personality. New York: Holt, Rinehart \& Winston.

Beirão, G., \& Cabral, J. A. S. (2007). Understanding attitudes towards public transport and private car: A qualitative study. Transport Policy, 14, 478-489.

Retrieved from http://dx.doi.org/10.1016/j.tranpol. 2007.04.009

Biddle, S. J. H., Gorely, T., Marshall, S. J., Murdey, I., \& Cameron, N. (2003). Physical activity and sedentary behaviours in youth: Issues and controversies. The Journal of The Royal Society for the Promotion of Health, 124(1), 29-33.

Bridges, J. W. (1925). An outline of abnormal psychology (3rd ed. rev.). Columbus, OH, US: R G Adams \& Co. Retrieved from http://dx.doi.org/10.1037/11640-001

Bronner, A. E. (1982). Decision styles in transport mode choice. Journal of Economic Psychology, 2(2), 81-101. Retrieved from http://dx.doi.org/10. 1016/0167-4870(82) 90026-5

Cao, X., \& Mokhtarian, P. L. (2005). How do individuals adapt their personal travel? Objective and subjective influences on the consideration of travel-related strategies for San Francisco Bay Area commuters. Transport Policy, 12, 291-302. Retrieved from http:/ /dx.doi.org/10.1016/j.tranpol. 2005.03.003

Chaplin, W. F., John, O. P., \& Goldberg, L. R. (1998). Conceptions of states and traits: Dimensional attributes with ideals as prototypes. Journal of Personality and Social Psychology, 54(4), 541-557.

Chau, J. Y., Merom, D., Grunseit, A., Rissel, C., Bauman, A. E., \& van der Ploeg, H. P. (2012). Temporal trends in non-occupational sedentary behaviours from Australian Time Use Surveys 1992, 1997 and 2006. International Journal of Behavioral Nutrition and Physical Activity, 9, 76. Retrieved from http:// dx.doi.org/10.1186/1479-58 68-9-76

Chowdhury, S., \& Ceder, A. A. (2013). A psychological investigation on public-transport users' intention to use routes with transfers. International Journal of Transportation, 1(1), 1-20. Retrieved from http://dx. doi.org/10.14257/ijt.2013. 1.1.01

Collins, C. M., \& Chambers, S. M. (2005). Psychological and situational influences on commutertransport-mode choice. Environment and Behavior, 37(5), 640-661. Retrieved from http://dx.doi.org/ $10.1177 / 0013916504265440$

Currie, G. (2012). The psychology of public transport behaviour. Presentation from Seminar on Traffic The Psychology of Transport Behaviour, Yarra Room, Melbourne Town Hall, April 19, 2012. Retrieved from http://www.sensible transport.org. au/sites/sensibletransport.org.au/files/Currie\%20PT \%20Psych\%20Presentation\%20FINAL.pdf

Dahalan, D., D’Silva, J. L., Abdullah, H., Ahmad, N., \& Ismail, I. A. (2014). Level of prejudiced among youth in Klang Valley, Malaysia towards public transport. Life Science Journal, 11(6), 365-373.

De Baere, S., Lefevre, J., De Martelaer, K., Philippaerts, R., \& Seghers, J. (2015). Temporal patterns of physical activity and sedentary behavior in 10-14 year-old children on weekdays. BMC Public Health, 15, 791. Retrieved from http://dx. doi.org/10.1186/ s12889-015-2093-7

Duvarci, M., Hult, N. A-M., Johansen, G. H., \& Munch, K. (2011). Social behaviour in public transportation. Retrieved from http://www.rucsdi gitaleprojekt bibliotek.dk/handle/1800/6064? mode $=$ full

Dziekan, A. (2008). Ease-of-use in public transportation: A user perspective on information and orientation aspects (Unpublished thesis). Royal Institute of Technology, Stockholm, Sweden.

European Commission. (2004). Reclaiming city streets for people: Chaos or quality of life? Luxembourg: 
Office for Official Publications of the European Communities. Retrieved from http://ec.europa.eu/ environment/ pubs/pdf/ streets_people.pdf

Glover, L. (2013). A communal turn for transport? Integrating community-owned transport and public transport for sustainable transport. Proceedings from People and the Planet 2013 Conference: Transforming the Future. RMIT University, Melbourne, Australia, July 2-4, 2013. Retrieved from http:// global-cities.info/wp-content/uploads/ 2013/11/ACommunal-Turn-for-Transport.pdf

Heath, Y., \& Gifford, R. (2002). Extending the theory of planned behavior: Predicting the use of public transportation. Journal of Applied Social Psychology, 32(10), 2154-2189. Retrieved from http://dx.doi. org/10.1111/j.1559-1816.2002. tb02068.x

Higurashi, H., \& Macer, D. (2001). The ethics of the heart and transport choices in Japan. Eubios Journal of Asian and International Bioethics, 11, 34-41. Retrieved from http://www.eubios.info/EJ 112/EJ112B.htm

Innocenti, A., Lattarulo, P., \& Pazienza, M. G. (2013). Car stickiness: Heuristics and biases in travel choice. Transport Policy, 25, 158-168. Retrieved from http://dx.doi.org/10.1016/j.tranpol.2012.11. 004

ITB News. (2013, April 29).Prof. Ade Sjafruddin: Angkutan umum, solusi kunci kemacetan Jakarta. Retrieved from http://www.itb.ac.id/news/itb_berita _3899.pdf

Johansson, M. V., Heldt, T., \& Johansson, P. (2006). The effects of attitudes and personality traits on mode choice. Transportation Research Part A, 40, 507-525. Retrieved from http://dx.doi.org/10.1016/ j.tra.2005.09.001

Juneman. (2010). Masalah transportasi kota dan pendekatan psikologi sosial. Psikobuana, 1(3), 173-189.

Kamargianni, M., Dubey, S., Polydoropoulou, A., \& Bhat, C. (2015). Investigating the subjective and objective factors influencing teenagers' school travel mode choice - An integrated choice and latent variable model. Transportation Research Part A, 78, 473-488. Retrieved from http://dx.doi. org/10.1016/j.tra.2015.06.011

Kim, J., Schmöcker, J-D., Bergstad, C. J., Fujii, S., \& Gärling, T. (2014). The influence of personality on acceptability of sustainable transport policies. Transportation, 41, 855-872. Retrieved from http://dx.doi.org/10.1007/s11116-013-9502-5

Lucente, R. (2008). Affectivity: Regulation, identity formation, and metaphorical thought. Psycho- analytic Social Work, 15(1), 1-27. Retrieved from http://dx.doi. org/10.1080/ 15228870802111757

Maister, D. H. (2005). The psychology of waiting lines. Harvard Business School Teaching Note, 9684-064. Retrieved from http://www.columbia.edu/ $\sim$ ww2040/4615S13/Psychology_of_Waiting_Lines.pdf

Mitrea, O., \& Kyamakya, K. (2013). "The journey is the purpose:" A concept for public transportation as social transient space. Proceedings from ITSC 2013: The 16th International IEEE Annual Conference on Intelligent Transportation Systems, The Hague, The Netherlands, October 6-9, 2013.

Moen, B-E. (2007). Determinants of safety priorities in transport - The effect of personality, worry, optimism, attitudes and willingness to pay. Safety Science, 45, 848-863. Retrieved from http://dx.doi. org/10.1016/j.ssci.2006.08.020

Morris, E. A., \& Guerra, E. (2015). Mood and mode: Does how we travel affect how we feel? Transportation, 42, 25-43. Retrieved from http://dx.doi.org/10.1007/ s11116-014-9521-x

Novaco, R. W. (2001). Psychology of transportation. International Encyclopedia of Social \& Behavioral Sciences (pp. 15878-15882). Amsterdam: Elsevier B.V. Retrieved from http://dx.doi.org/10.1016/B008-043076-7/01377-2

Owen, N., Healy, G. N., Matthews, C. E., \& Dunstan, D. W. (2010). Too much sitting: The populationhealth science of sedentary behavior. Exercise and Sport Sciences Reviews, 38(3), 105-113. Retrieved from http://dx.doi.org/10.1097/JES.0b013e3181e373a2

Owen, N., Sugiyama, T., Eakin, E. E., Gardiner, P. A., Tremblay, M. S., \& Sallis, J. F. (2011). Adults' sedentary behavior: Determinants and interventions. American Journal of Preventive Medicine, 41(2), 189-196. Retrieved from http://dx.doi.org/10.1016/ j.amepre.2011.05.013

Peavler, M. (2012). Worksite intervention to reduce sedentary time (Unpublished master's thesis). East Carolina University, Greenville, NC, United States.

Popuri, Y., Proussaloglou, K., Ayvalik, C., Koppelman, F., \& Lee, A. (2011). Importance of traveler attitudes in the choice of public transportation to work: Findings from the Regional Transportation Authority Attitudinal Survey. Transportation, 38, 643-661. Retrieved from http://dx.doi.org/10.1007/s11116011-9336-y

Rizky, W. O. (2014). Rencana piñataan sistem transportasi DKI Jakarta. Selasar Politik. Retrieved from https://www.selasar.com/politik/rencana-penataansistem-transportasi-dki-jakarta 
Saunders, T. J. (2013). The health impact of sedentary behaviour in children and youth (Unpublished thesis). School of Human Kinetics, Faculty of Health Sciences, University of Ottawa, Canada.

Sawka, K. J., McCormack, G. R., Nettel-Aguirre, A., Hawe, P., \& Doyle-Baker, P. K. (2013). Friendship networks and physical activity and sedentary behavior among youth: A systematized review. International Journal of Behavioral Nutrition and Physical Activity, 10, 130. Retrieved from http://dx. doi.org/10.1186/1479-5868-10-130

Schwanen, T., \& Mokhtarian, P. L. (2005). What affects commute mode choice: Neighborhood physical structure or preferences toward neighborhoods? Journal of Transport Geography, 13, 83-99. Retrieved from http://dx.doi.org/10.1016/j.jtrangeo.2004. 11.001

Sheller, M., \& Urry, J. (2004). The city and the car. International Journal of Urban and Regional Research, 24(4), 737-757. Retrieved from http://dx .doi.org/10.1111/1468-2427.00276

Sohn, K., \& Yun, J. (2009). Separation of cardependent commuters from normal-choice riders in mode-choice analysis. Transportation, 36, 423436. Retrieved from http://dx.doi.org/10.1007/s 11116-009-9209-9

Steg, L. (2005). Car use: lust and must: Instrumental, symbolic and affective motives for car use. Transportation Research Part A, 39, 147-162. Retrieved from http://dx.doi.org/10.1016/j.tra.2004. 07.001
Steg, L., \& Schuitema, G. (2007). Behavioural responses to transport pricing: A theoretical analysis. In T. Gärling \& L. Steg (Eds.), Threats to the quality of urban life from car traffic: Problems, causes, and solutions (pp. 347-366). Amsterdam: Elsevier.

Stradling, S., Carreno, M., Rye, T., \& Noble, A. (2007). Passenger perceptions and the ideal urban bus journey experience. Transport Policy, 14, 283292. Retrieved from http://dx.doi.org/10.1016/j. tranpol.2007.02.003

Sumaedi, S., Bakti, I. G. M. Y., Astrini, N. J., Rakhmawati, T., Widianti, T., \& Yarmen, M. (2014). Public transport passengers' behavioural intentions paratransit in Jabodetabek-Indonesia. Singapore: Springer. Retrieved from http://dx.doi. org/10.1007/978-981-4585-24-8

Transport Advisory Committee. (2014). Report on study of road traffic congestion in Hong Kong. Retrieved from http://www.thb.gov.hk/eng/ boards/ transport/land/ Full_Eng_C_cover.pdf

Vázquez-Nava, F., Treviño-Garcia-Manzo, N., VázquezRodríguez, C. F., \& Vázquez-Rodríguez, E. M. (2013). Association between family structure, maternal education level, and maternal employment with sedentary lifestyle in primary school-age children. Journal de Pediatria (Rio J.), 89(2), 145-150. Retrieved from http://dx.doi.org/10.1016/j.jped. 2013.03.009

Zaborowski, R. (2013). Affectivity in its relation to personal identity. Retrieved from http://www.ihnpan. waw.pl/redakcje/organon/44/3_zaborowski.pdf 